\title{
Strategi Pemasaran Perguruan Tinggi Swasta
}

\author{
H. Mochamad Edwar Romli \\ Dosen PNS DPK L2 Dikti
}

\begin{abstract}
ABSTRAK
Saat ini perguruan tinggi semakin banyak dan ragam jumlahnya. Kondisi seperti ini menimbulkan persaingan atau kompetisi. Sehubungan dengan hal ini perguruan tinggi khususnya swasta harus melakukan kegiatan pemasaran dengan menggunakan strategi yang gencar. Strategi pemasaran harus mempertimbangkan perilaku beli konsumen, segementasi pasar, dan strategi pemasaran yang dapat digunakan, karena tidak mungkin seluruh pasar dapat dimasuki. Langkah yang dapat ditempuh adalah pilih strategi pasar yang sesuai, pilih pasar yang potensial saja, gunakan kombinasi strategi pemasaran yang ada, dan dalam melakukan pemasaran harus diperhatikan aspek produk, harga, distribusi, dan promosi.
\end{abstract}

Kata kunci: pemasaran, segmentasi pasar, promosi, dan strategi pemasaran.

\section{A. PENDAHULUAN}

Dewasa ini jumlah perguruan tinggi semangkin banyak baik perguruan tinggi negeri maupun swasta terutama perguruan tinggi swasta (PTS) yang baru berdiri di kotakota bahkan sampai ke daerah-daerah tingkat II (Kabupaten Kota). Disatu sisi ini tentu sangat baik karena akan membantu pemerintah dalam peningkatan kualitas sumber daya manusia (SDM) yang sangat dibutuhkan dalam penganggura. Tetapi disisi lain dengan banyaknya tumbuh atau munculnya perguruan tinggi swasta baru maupun perguruan tinggi baru itu telah menimbulkan persaingan atau kompentisi yang tidak baik diantara mereka. Perguruan tinggi negeri merebut jumlah calon mahasiswa dengan banyak dengan biaya sangat murah atau sangat mahal. Tetapi besar maksudnya sebagai perguruan tinggi negeri (PTN) maka calon mahasiswa berebut untuk menjadi mahasiswanya. Calon mahasiswa hanya melihat status dan keberadaan dan pengaruh studynya.

Kompentisi itu menyebabkan PTS mengalami kesulitan menerima mahasiswa sehingga jumlah PTS menjadi sangat menurun ini menyebabkan kehidupan PTS menjadi redup dan sulit kehidupannya karena jumlah mahasiswanya sangat sedikit. Saat ini sulit bagi PTS untuk menerima mahasiswa lebih dari 2000 orang. Sementara PTN kelas Mandiri menerima mahasiswa lebih dari 2500 orang.

Dengan jumlah mahasiswa yang sedikit, PTS sulit untuk menjalankan tugas-tugas dari Dosen Perguruan tinggi dan menyejaterakan Dosendosennya. Supaya Mahasiswa PTS tetap dapat mempertahankan kehidupannya agar oprasional PTS dapat selalu berjalan, maka sudah tugas Mahasiswasaat ini PTS melakukan kegiatan pemasaran agar PTS dapat lebih dikenal konsumen sehinggga jumlah mahasiswanya bebih meningkat. Sehubungan dengan ini maka masalah yang dinginkan adalah faktor strategi pemasaran yang harus dilakukan PTS dan bagaimana PTS harus melaksanakan strategi pemasaranya. Sehubungan dengan masalah yang dinginkan ini maka tugas pemimpin adalah mengatasi 
strategi pemasaran yang harus dilaksanakan PTS Rektor mengatakan bagaimana jelasnyaPTS harus melaksanakan Strategi pemasaran yang jumlah dipilihnya itu.

\section{B. PEMBAHASAN}

Liga Suryadana Oktaria (2005) mengatakan pemasaran adalah salah satu kegiatan perusahaan dimana secara langsung berhubungan dengan konsumen. Dari pendapat ini diketahui melalui pemasaran akan produk kita dengan konsumen, termasuk mengingatkan produk kita dalam ingatan konsumen sehingga dapat mengerakan konsumen untuk membeli produk yang kita pasarakan itu. Memang konsumen dapat saja lupa akan produk kita, oleh karena itu perlu terus diingatkan melalui pemasaran yang kita lakukan.

Burhari Alma (2010) mengatakan pemasaran adalah menghubungkan penjual dengan pembeli potensial. Pemasaran adalah memberikan sebuah standar kehidupan. Selajutnya Hermawan Kartajaya mengatakan (2007) Pemasaran adalah suatu proses dalam menentukan permintaan konsumen akan barang dan jasa, memotivasi penjual, mendistribusikan konsumen dengan keuntungan perolehannya.

Buchari Alma (2007) mengatakan pemasaran adalah sekumpulan aktifitas yang ditunjukan untuk mendefinisikan dan melaksanakan pertukaran. Sedangkan Peter Drucker (Buchari Alma, 2007) mengatakan pemasaran bertambah sekedar perluasan penjualan, pemasaran meliputi keseluruhan bisnis dan harus dilihat dari sudut pelanggan.

Menurut Sofjan Assauri (2018) Pemasaran adalah hasil prestasi kerja kegiatan usaha yang berkaitan dengan mengalirnya barang dan jasa dari produsen sampai ke konsumen.
Sebenarnya sebelum barang dan jasa dari produsen sampai ke konsumen sebenarnya sebelum barang atau jasa itu diroduksi sudah dipikirkan pemasaran itu dilakukan.

Dari pengertian pemasaran diatas dapat ditarik kesimpulan sebagai berikut :

1. Pemasaran itu berkaitan dengan menghubungkan penjual dengan pembeli pemasaran berarti menjalin hubungan penjual dengan pembeli hubungan ini sangat penting untuk menciptakan pembeli dan pelanggan

2. Pemasaran itu berkaitan dengan sebuah standar kehidupan. Pemasaran itu menentukan standar kehidupan oleh karena itu produk yang dipasarkan harus dapat dikaitkan dengan ukuran kehidupan seseorang. Ini artinya kita harus menjual produk yang sesuai ukuran kehidupan konsumen, sehingga produk itu tidak akan menjatuhkan gengsi mereka.

Hal ini berarti ketika pemasaran itu dilakukan maka kita sebagai pemasaran harus mengetahui beberapa hal sebagai berikut ini yaitu :

a. Pasar sasaran (Target Market) yang akan dituju oleh produsen yang kita pasarkan.

b. Segmentasi pasar adalah mengelompokan konsumen berdasarkan syarat-syarat tertentu.

Sebelum pemasaran produk kita lakukan maka pasar yang besar itu harus dibagi-bagi atau dikelompokkelompokan terlebih dahulu sehingga kita dapat mengakhiri kemana produk kita harus dipasarkan.

Mungkin tidak perlu seluruh pasar itu harus dimasuki tetapi cukup pasar- 
pasar sangat potensial saja yang disana itu banyak konsumen yang membutuhkan produk yang kita hasilkan.

Menurut Sofjon Assauri (2018) segmentasi pasar terdiri dari :

\section{Segmentasi berdasarakan geografi yaitu segmentasi menurut wilayah}

2. Segmentasi berdasarkan demografi yaitu pengelompokan konsumen berdasarkan demografi (kependudukan) seperti jumlah anggota keluarga, pendidikan, kelas sosial, keturunan dan sebagainya.

3. Segmentasi berdasarkan tingkat kelompok (berkelompok) yaitu segmentasi yang berdasarkan gaya hidup (lifestyle) dan kepribadian personality.

Sebelum melakukan pemasaran haeus diperhatikan segmentasi pasar yang akan dituju. Apakah pasar yang akan dituju segmentasi atas dasar demografis, geografis, penilaian atau geografis, pasar yang besar harus disegmen-segmen dahulu sehingga kita dapat menentukan segmen yang menjadi target pasar atau pasar sasaran (target pasar) pilih pasar sasaran yang sangat potensial.

Kalau kita kan melakukan pemasaran, maka kita harus memperhatikan prilaku beli konsumen untuk membeli produk. Secara garis besarnya menurut William J.Stanton (2000) ada 2 faktor yang mempengaruhi konsumen untuk membeli yaitu :

1. Pengaruh faktor sosial budaya yang dibagi lagi atas budaya, tingkat sosial, dan keluarga. Pengaruh keluarga dan teman sangat besar terhadap penilaian konsumen untuk membeli. Bila saja teman atau keluarga membatalkan seseorang untuk membeli.

2. Faktor piskologi konsumen.

Faktor lain yang mempengaruhi konsumen untuk membeli adalah faktor piskologis konsumen tersebut yang dapat terdiri dari penyelaman belajar, kepribadian, sikap dan keyakinan dan konsep diri. Faktor piskologis konsumen yang mempengaruhi piskologis konsumen untuk membeli produk harus diperhatikan sebelum pemasaran dilakukan. Ketahui bagaimana sikap konsumen dan pengalaman belajar konsumen dengan produk kita. Juga perlu diketahui konsep diri konsumen terhadap produk kita. Konsumen yang telah memiliki konsep diri negatif terhadap produk kita memang sulit untuk dirubah.

Secara umum bila faktor piskologis yang mempengaruhi konsumen untuk membeli ini masih bersifat negatif maka kita harus mengubah sikap-sikap tersebut terlebih dahulu sebelum melakukan aktifitas pemasaran supaya pemasaran yang kita lakukan dapat berhasil.

Begitu juga faktor sosial budaya sangat berpengaruh terhadap penilaian beli konsumen. Oleh karena itu sebagai marketer kita harus cermat untuk melakukan pemasaran bila di tinjau dari sudut sosial budaya ini.

Penilaian beli konsumen bila ditinjau dari sudut sosial budaya sangat dipengaruhi olah Faktor kemampuan ekonomi dan keluarga oleh karena itu sebagai marketer kita harus panadi-pandai untuk menentukan lokasi pemasran yang akan kita masuki.

Strategi Pemasaran (Buchari Alma : 2010) menyatakan strategi rencana prudential atau mendasar 
penetapan oleh keseluruhan dari bisnis sedangkan statistik adalah inflementasi dari strategi yang menempel pada bagian-bagian tertentu dalam kegiatan bisnis. Bagi para pedagang strategi didalam pemasaran adalah bagian dari strategi tempur untuk memenangkan peperangan.

$$
\text { Sofjan }
$$

Assauri

mengatakan strategi pemasaran mempunyai peranan sangat penting untuk keberhasilan usaha dan pemasaran. Strategi pemasan itu mengatakan rencana yang menyakut, terpadu dan menyatu dibidang pemasaran, yang memberikan paduan tentang kegiatan yang akan dilakukan atau dijalankan untuk dapat mencapai tujuan pemasaran suatu perusaan yang dalam hal ini tujuan perguruan tinggi swasta (PTS).

Dari pengertian strategi pemasaran tersebut diatas dapat disimpulkan bahwa strategi pemasaran itu merupakan suatu rencana dibidang pemasaran tentang kegiatan yang akan dijalankan untuk mencapai tujan pemasaran suatu perusahaan. Didalam strategi pemasaran itu upayaupaya yang dilakukan untuk mencapai tujuan pemasaran yaitu dapat memenuhi keinginan konsumen sehingga mereka memperoleh kepuasan produk kita tersebut dan akan membeli ulang bila mereka mendapat kepuasan. Ini sebenarnya sangat diharapkan terjadi melalui aktifitas pemasaran yang sudah dilakukan itu.

Ada berbagai strategi pemasaran yang dapat diterapkan dimasyarakat menurut Buchari Alma (2010) adalah :

1. Strategi pemasaran dalam berbagai situasi pemasaran. Setiap barng atau jasa yang disewakan dipasar dapat mempengaruhi berbagai situasi pemasaran yang berbeda di tinjau dari sudut permintaanya yaitu :

a. Permintaan Negatif

Ada konsumen memiliki permintaan negatif seperti tidak mau menjadi guru dengan berbagai alasan.

Untuk itu faktor-faktor penyebab itu perlu diatasi seperti dengan mengintrosfeksikan bahwa peluang untuk menjadi guru PNS masih terbuka lebar dari pada lulusan yang lain. Tentu saja masih ada informasi-informasi lain yang dapat diberikan misalnya tentang jenjang karir seorang guru.

b. Tidak ada permintaan atau ada permintaan lain ( terpendam)

Bisa jadi disuatu daerah tidak ada permintaan untuk masuk perguruan tinggi atau permintaanya itu lain (terpendam atau tidak terlihat dengan nyata). Oleh karena itu melalui strategi pemasaran yang digunakan kita harus dapat menciptakan adanya permintaan untuk memasuki suatu perguruan tinggi. Cari sebab apa faktor penyebanya didaerah itu tidak ada permintaan terhadap produk kita, sedangkan di tempat lain ada. Lakukan strategi pemasaran untuk menciptakan adanya permintaan di setiap yang tidak ada permintaanya itu atau ditempat yang permintaan yaitu lain (terpendam). Disinilah pemasaran harus dilakukan atau berperan untuk menetapkan adanya permintaan sehingga tercipta suatu kehidupan.

2. Strategi pemasaran dengan bauran pemasaran (marketing mix).

Bauran pemasaran (marketing mix) menyatakan variabelvariabel pemasaran (produk, 
harga, promosi dan distribusi) yang masih dapt dikontrol oleh pemasaran dan dipromosikan dalam rangka meningkatkan omset penjualan.

Sofjan Asswari (2018) mengatakan bahwa pemasaran adalah kombinasi variabel atau kegiatan yang menyatakan inti dari sistem pemasaran, variabel yang dapat dikembalikan oleh perusahaan untuk mempengaruhi mengapa konsumen dalam pasar sasaranya.

Bauran pemasaran menetapkan komposisi terbaik dari ke empat komponen atau variabel pemasaran untuk mendapat mencapai sasaran pasar yang dituju sekaligus mencapai tujuan dan sasaran perusahaan (perguruan Tinggi).

Keempat unsur atau variabel bauran pemasaran itu adalah produk, harga distribusi, dan promosi. Kerena ada 4 unsur dalam bauran pemasaran itu maka ada 4 strategi pemasaran yang harus dilakukan yaitu :

a. Strategi produk

b. Strategi harga

c. Strategi saluran distribusi

d. Strategi promosi

Keempat strategi pemasaran itu akan diuraikan satu persatu berikut ini :

a) Strategi produk

Dalam strategi produk ini yang perlu dilakukan adalah produk itu perlu terus dikembangkan ke arah yang lebih baik, tetapi tetap menjaga kualitas produk itu. Oleh karena itu untuk pengembangan produk ini diperlukan kreatifitas dan inovasi dari seluruh karyawan yang ada. Dengan pengembangan produk ini maka konsumen dapat merasa puas dan kepuasan mereka sebagai konsumen dapat dijaga.

Strategi produk ini sangat penting. Pemilihan jenis produk akan menentukan strategi yang akan digunakan. Perlu diperhatikan fakto-faktor yang terkait dengan suatu produk seperti yaitu :

$>$ Kualitas produk

$>$ Penampilan produk

$>$ Pilihan produk yang ada

$>$ Harga produk

$>$ Merek produk

$>$ Kemasan produk

$>$ Jenis produk

$>$ Macam produk

$>$ Jaminan produk

$>$ Pelayanan atas produk tersebut

Dalam stategi produk ini yang sangat diperlukan itu tidak hanya berkaitan dengan produk itu sendir, tetapi juga mennyakut layanan penawaran produk, dan layanan purna jual dll.

b) Strategi harga

Dalam mentetapkan strategi harga harus dinyatakan agar produk yang dipasarkan itu merupakan produk dengan harga yang mampu bersaing, maksudnya produk yang kita hasilkan itu tidak lebih mahal tetapi juga tidak lebih murah dari produk lain yang sejenis. Ini artinya produk yang kita hasilkan itu harus mampu bersaing kalau lebih murah nanti kita dikatakankan sebagai produk murahan. Sebaliknya bila produk kita lebih mahal nanti produk kita itu dikatakan oleh konsumen sebagai produk yang mahal (kemahalan). Oleh karena itu timbul istilah bahwa produk kita itu mampu bersaing dengan produk lain.

c) Strategi saluran distribusi 
Supaya suatu produk dapat mencapai tujuanya dan target market, maka terhadap produk itu harus dilakukan kegiatan penyaluran atau distribusi produk dari produsen kepada konsumen. Dalam hal ini produk yang dilakukan itu bukan berupa produk barang, tetapi ini promosi tentang produk tersebut yang sudah dikemas dalam suatu market, booket atau bukan promosi lainya dalam bentuk yang menari,tidak menoton atau membosanka, atau menimbulkan kelelahan bagi mereka yang membacan, bahan promosi itu disebarkan melalui suatu jalur pemasaran atau jalur distribusi dengan menggunakan cara-cara tertentu sehingga cara promosi yang dapat digunakan bahan tersebut mencapai target pasar kita kehendaki akan dituju.

d) Strategi promosi

Promosi menetapkan kegiatan penting didalam pemasaran yang dapat menjadi suatu strategi dalam memasarkan produk termasuk produk dalam bentuk penawaran tinggi.

Perguruan tinggi sangat penting memasarkan dirinya agar lebih dikenal oleh konsumen. Eman Suherman (2008) mengatakan promosi adalah proses komunikasi yang berisi penyampaian data dan informasi, manfaat serta keunggulan produk kepada hallayak atau masyarakat oleh petugas promosi dengan tujuan menarik perhatian sasaran promosi agar menjadi kenyataan dilapangan.

Promosi bukan hanya menyampaikan informasi tentang suatu produk, tetapi melalui informasi itu petugas promosi harus dapat mengunggah daya tarik konsumen terhadap produk yang dpromosikan agar konsumen mau membeli produk tersebut. Promosi ditujukan kepada pasar sasaran ( target Pasar) dengan menarik bukan hanya sekedar menggunakan produk saja dengan menggunakan strategi pemasaran yang sudah ada diperhitungkan terlebih dahulu,

Konsumen tidak akan membeli produk yang kita pasarkan bila mereka belum mengenal produk tersebut. Dengan menggunakan strategi pemasaran dalam bentuk promosi, maka konsumen akan mengetahui atau mengenal suatu promosi produk sehingga mereka dapat tertarik dan tergugah untuk membeli suatu produk. Begitu pula sebaliknya. Tentu saja sangat diharapkan produk yang dibeli itu dapatmemuaskan diri konsumen sehingga konsumen akan membeli ulang. Inilah tujuan akhir yang diharapkan dari usaha kegiatan pemasaran.

Pemasaran itu membutuhkan daya cipta atau gaya koleksi kita sebagai pemasar (marketer). Kita harus kreatif menciptakan ide-ide pemasaran dengan berbagai macam cara agar konsumen mau membeli produk kita, seperti dikemukan oleh William J. Staton (2000) Pemasaran adalah mencari dan realisai sebuah standar hidup sehubungan dengan pengertian ini maka marketer harus melakukan kegiatan sebagai berikut :

a. Menyelidiki dan mengetahui apa yang diinginkan konsumen

b. Merencanakan dan mengembangkan produk untuk mengerti keinginan konsumen

c. Membutuhkan cara terbaik menentukan harga promosi dan distribusi produk yang dapat meluaskan keinginan konsumen.

\section{KESIMPULAN DAN SARAN \\ 1. Kesimpulan}


Dari hasil kesimpulan dan kajian yang telah dilakukan dapat ditarik kesimpulan sebagai berikut :

a. Perguruan tinggi swasta ini harus melakukan kegiatan pemasaran untuk mengatasi kompetisi, yang sedemikian gencar diantara sesama perguruan tinggi dengan menggunakan berbagai macam strategi pemasaran

b. Untuk menggunakan strategi pemasaran harus dipertimbangkan perilaku beli konsumen, segmentasi pasar, dan strategi pemasaran yang dapat digunakan.

c. Tidak mungkin seluruh pasar yang ada dapat dimasuki karena pasar itu sangat luas.

2. Saran

Sehubugan kesimpulan diatas dapat dikembangkan sasaran sebagai berikut :

a. Pilih strategi pemasaran yang sesuai dan tepat kaena tidak seburuk strategi itu sesuai dan tepat digunakan ditempat yang sama

b. Pilih pasar yang potensial saja sehingga tidak seluruh pasar harus dimasuki karena begitu luasnya pasar tersebut.

c. Dapat digunakan kombinasi strategi pemasaran yang ada.

d. Dalam menetapkan strategi pemasaran itu harus diperhatikan aspek produk, harga, distribusi dan promosi. e. Penetapan harga produk sebaiknya bersaing sehingga harga produk kita tidak lebih mahal atau lebih murah dari produk sejenis yang dihasilkan pemasaran yang alin. Karena harga ini sangat menentukan pemasaran yang kita lakukan.

\section{DAFTAR PUSTAKA}

Alma, Buchari. 2010. Kewirausahaan, Edisi Revisi. CV Alfabeta, Bandung

Kartajaya, Hermawan, at. al. 2007. Memenangkan Persaingan Dengan Segitiga Positioning, Diferensiasi Dan Brand. Mizan Pustaka, Bandung.

Suherman, Eman. 2008. Business Entrepreuneur : Modal, Model, Modul Kewirausahaan. Cetakan Kesatu. CV. Alfabeta, Bandung

Suryadana, Liga. Oktaria, Vanny. 2005. Pemasaran Parawisata. CV. Alfabeta, Bandung

Stanton, William J. 2000. Prinsip Pemasaran. Erlagga, Jakarta.

Assauri, Sofjan. 2018. Pemasaran. PT. Raja Grafindo Persada, Depok. 